\title{
Exploring Student's Engagement in Learning Vocabulary Through Animation Videos
}

\author{
Sri Rahayu ${ }^{1}$, Yousef Bani Ahmad ${ }^{2}$, Acep Bahrum Kamil ${ }^{3 *}$ \\ ${ }^{1}$ (English Education Departement, University of Singaperbangsa Karawang, Indonesia). \\ ${ }^{3}$ (English Education Departement, University of Singaperbangsa Karawang, Indonesia). \\ ${ }^{2}$ (English Education Departement, University of Singaperbangsa Karawang, Indonesia). \\ * Corresponding Author. E-mail: ${ }^{1}$ Sr455186@gmail.com
}

\begin{tabular}{|l|l|l|}
\hline Receive: $13 / 05 / 2021$ & Accepted: 23/08/2021 & Published: 01/10/2021 \\
\hline
\end{tabular}

\begin{abstract}
Abstrak
Tujuan penelitian ini adalah untuk melihat bagaimana keterlibatan siswa pada pembelajaran vocabulary menggunakan video animasi. Jenis penelitian ini adalah penelitian qualitative. Partisipan dalam penelitian ini adalah siswa kelas delapan di MTs Al Hasan Karawang. Sampel penelitian adalah 3 orang siswa yang dipilih berdasarkan rekomendasi dari guru bahasa inggris, dari siswa yang paling aktif hingga menengah dalam pembelajaran bahasa inggris. Data dikumpulkan melalui dua instrument, yaitu melalui wawancara dan dokumentasi. Dalam dokumentasi, siswa di persilahkan untuk menonton materi pembelajaran menggunakan video animasi dengan durasi sekitar 5 menit. Lalu setelah itu, siswa di beri soal untuk menuliskan kosa kata baru yang mereka dapat dari video animasi sekitar 10-15 kata. Dalam wawancara, peneliti menggunakan semi-structure interview sebagai desain penelitian. Siswa di berikan beberapa pertanyaan terkait tiga aspek keterlibatan siswa, yaitu aspek kognitif, behavior, dan emosional. Data penelitian berupa transkip dari rekaman berbicara singkat dan jawaban terkait interview yang telah di lakukan. Dari penelitian ini ditemukan bahwa pembelajaran vocabulary menggunakan video animasi dapat membantu siswa dalam pembelajaran kosa kata (kognitif), menunjukan reaksi positif terhadap pembelajaran (emosional), dan berpartisipasi aktif dalam pembelajaran dikelas (behavior).
\end{abstract}

Kata Kunci: keterlibatan siswa, kognitif, behavior, emosional, kualitatif

\begin{abstract}
The purpose of this study was to see how students were involved in vocabulary learning using animated videos. This type of research is qualitative research. The participants in this study were eighth grade students at MTs Al Hasan Karawang. The research sample was 3 students who were selected based on the recommendation of the English teacher, from the most active to intermediate students in learning English. Data were collected through two instruments, namely through interviews and documentation. In the documentation, students are invited to watch learning materials using animated videos with a duration of about 5 minutes. Then after that, students were given questions to write down the new vocabulary they got from the animated video of about 10-15 words. In the interview, the researcher used semi-structured interview as the research design. Students were given several questions related to three aspects of student involvement, namely cognitive, behavioral, and emotional aspects. The research data is in the form of transcripts of short speaking recordings and answers related to interviews that have been carried out. From this study it was found that vocabulary learning using animated videos can help students in learning vocabulary (cognitive), showing positive reactions to learning (emotional), and actively participating in classroom learning (behavior).
\end{abstract}

Keywords: student engagement, cognitive, behavior, emotional, qualitative. 


\section{Introduction}

Humans are social creatures that interact with each other, these activities require tools, means, or media, namely language. In language learning, we recognize several aspects that support the success of the language, one of which is the vocabulary. Language will not be meaningful without sufficient vocabulary. Therefore, it is important for a student to learn Vocabulary. According to Wilkins (Thonbury, 2002: 13) at site as (Mashhadi \& Jamalifar, 2015), states that "little can be communicated without grammar, but nothing can be communicated without vocabulary". From this statement it can be concluded that learning vocabulary takes precedence over grammar. A similar opinion is expressed by Harmer (1992: 153) at site as (Mart, 2012) "if language structure makes up the skeleton of language, then it is vocabulary that provides the vital organs and the flesh".

The importance of students' engagement in vocabulary makes students' motivations decline, so they don't have the passion to learn vocabulary. Therefore teachers need and use interesting media to attract students and make good engagement in the class. Students Engagement is not just a motivational act and is based on observing student action. Also consider considering some of the factors in learning that remain hidden from a teacher's view. According to Frederick et al., (2004) at site as (Mo \& Singh, 2015), three factors that make up engagement are (1) behavioral (including the actions they take), (2) emotional (including student act), (3) cognitive (includes all student efforts that they invest in studying and maintaining the material). It is important for students to experience the three stages of involvement, for example in learning New Vocabulary. On the pandemic of the covid-19 which is presently plaguing the world. School studies were transformed into online learning. Students study at home using modern technology. With modern technology such as computers and smartphones during academics, creating new methods in environments that combine media with learning such as the New Vocabulary for students, which has become a positive step to increase engagement in learning for students to be more motivated to focus more on their learning.

Thus, researchers feel the need to take action to see how students are involved when learning to use modern technology such as animated videos. Researchers use animated videos as a medium to study vocabulary. The primary purpose is to help students' learning to be more effective, interesting and fun and thus increase their learning motivation to collect and improve their vocabulary. Her animated video is a collection of word-word videos based on a theme.

\section{Method}

The study is conducted at MTS al hasan Dauwan Barat Karawang. With a focus on 3 students, who will be on the interview using an instrument semi-structure interview. In this research, the researcher used design of qualitative research which is a method of research that attempt to describe and interpret the objects in accordance with reality. And the processed data will analyzed by Thematic Analysis. Thematic Analysis is one of the most common methods for analyizing data with the goal of identifying pola or identifying a theme using data has already been collected by the researcher (Braun \& Clarke, 2006).

\section{FINDINGS AND DISSCUSION}

There are three findings of students' engagement in learning vocabulary through 
Animation Videos. The participate, (emotional students), job given, obeying the concentrate, focus, absorb (cognitive rules to actively participating in organizations students), enthusiasm, enjoyment, pleasure, in schools. And also students' interest in and satisfaction in learning academic activities learning in class (behavior students).

Table 1. Student teacher demography information

\begin{tabular}{lllllll}
\hline $\begin{array}{l}\text { Participants } \\
\text { (Pseudonym) }\end{array}$ & Gender & Age & $\begin{array}{l}\text { Linguistics } \\
\text { Background }\end{array}$ & $\begin{array}{l}\text { Education } \\
\text { Background }\end{array}$ & $\begin{array}{l}\text { Length of } \\
\text { English } \\
\text { Learning } \\
\text { Experience }\end{array}$ & $\begin{array}{l}\text { Social- } \\
\text { Economy } \\
\text { Bacground }\end{array}$ \\
\hline Alya & Female & 13 & $\begin{array}{l}\text { Sundanese } \\
\text { Indonesian }\end{array}$ & $\begin{array}{l}\text { A Junior } \\
\text { High } \\
\text { student } \\
\text { A Junior }\end{array}$ & 5 years & Medium \\
Rosa & Female & 13 & $\begin{array}{l}\text { Sundanese } \\
\text { Indonesian }\end{array}$ & $\begin{array}{l}\text { High } \\
\text { Student } \\
\text { A Junior } \\
\text { Sigh }\end{array}$ & 5 years & Medium \\
Sahara & Female & 13 & $\begin{array}{l}\text { Sundanese } \\
\text { Indonesian }\end{array}$ & $\begin{array}{l}\text { Student } \\
\text { Studium }\end{array}$ & Medium \\
\hline
\end{tabular}

Adopted from (Pravitasari \& Yanto, 2020)

However, before analyzing the results of interviews with participants, students were given the opportunity to recheck the results of the interview transcripts. It aims to build trust between researchers and participants. Member Inspections are beneficial for establishing data trust and upholding data integrity when (re)constructing data (Harvey \& McBean, 2015). And the participant were agreed to be volunteer. They were expressed their experiences in learning vocabulary through animation video.

\section{Students' Cognitive Engagement in learning Vocabulary through Animation Videos}

The students were given animated videos on "my house" theme, after which they were interviewed casually regarding the study. This can be traced from interviews exploring students' involvement in vocabulary learning using animated videos.

Researcher : Does the study of using this animated video add to or make it easier for you to collect your vocabulary?

Participant 1 : yes ma'am, increase a little bit. alhamdulillah, the material is easy to understand, if use video it's easy

Participant 2 : yes, increase more. Participant 3 : yes, increase.

Researcher : Is there any vocabulary you remember from yesterday's animated video study? Participant 2 : Book slap, tissue Box, alarm clock, fan, tap walker. Participant 3 : door, floor, roof, window, Mirror.

Based on interview transcriptions, it illustrated that 
students were actively engaged to learning Vocabulary. Animation videos make them focus more on learning vocabulary, so they can actively name the vocabulary they remember.

2. Students' Emotional Engagement in learning Vocabulary through Animation Videos

Students' emotional shows a positive reaction from students regarding vocabulary learning using animated videos. The reaction shows the students' emotions towards the learning.

Researcher : Is learning vocabulary using this video interesting? And what part did you find interesting?

Participant 1 : I think It's helpful ma'am, especially since animation videos are fun. The part when watching the Video and continues to be asked to collect the words ma'am

Participant 2 : It's more fun, more interesting to understand. In the image section

Participant 3 : It's fun, so it goes deeper into the brain. When there's a singing

Based on the interview transcription, it shows positive reactions from students. Animated videos have interesting things for them to learn and make it easier for them to learn.

3. Students' Behavior Engagement in learning Vocabulary through Animation Videos

Behavioral engagement can be in the form of simple things such as the job given, obeying the rules to actively participating in organizations in schools.

Researcher : How was the learning experience in class, what do you do if there is material that you don't understand?
Participant 1 : I'm discuss with friends and ask the teacher too, ma'am.

Participant 2 : I'm always disscus with other, and always collecting assignment On Time.

Participant 3 : l'ts more easier to understand, than online learning that's nothing use video. And l've always discussion with friends.

Based on interviews with participants, and documentation of student assignments, it can be concluded that students are very actively participating in learning using animated videos. They always discuss with friends or teachers if there is something they do not understand.

\section{Disscuss}

\section{Mediated Animation Videos assist student in learning vocabulary (cognitive engagment)}

In the results of the researcher findings, the researcher found several opinions regarding the effectiveness of the animated video for their Vocabulary learning. All participants have the same opinion regarding this matter, namely that they think that animated videos have an important role in their vocabulary collection. Furthermore, animation videos can aid in the representation of a material (Zakirman \& Hidayanti, 2017). When the researchers asked about the vocabulary they remembered, they were able to mention the vocabulary they had learned, they were also able to mention the meaning of the vocabulary that the researcher had taught before. In addition, they also said that animated videos could increase their vocabulary. This preception was supported by (Sydorenko, 2010) who states that videos can not only be used to learn new 
vocabulary, but also help recall subsequent vocabulary.

\section{Positive reaction student in learning vocabulary through animation videos (emotional engagement)}

In these students' emotional, students show positive reactions to Vocabulary learning using animated videos. Participants said that there was no difficulty in using animated videos as their learning media. Furthermore, they all have the same perception regarding positive reactions to learning to use this animated video, namely participants say that animated video is a helpful and also interesting medium to use. In the animated video there are several things that make them interested, such as pictures, songs and interesting views. So that makes them happier to learn compared to learning that does not use animated videos. This opinion is supported by a statement from Koning and his Colleagues (2019) at site as (Masitah, Pamungkasari, \& Suminah, 2020) stated that animation Videos are beneficial learning outcomes in the form of motor skills and a sense of accomplishment static pictures are interior to cognitive tasks.

3. Active participation of students in class in learning vocabularythrough animation videos (students behavior)

In students' behavior, the researcher found that students understood the material that the researcher gave using animated videos. Students' behavior is Positive conduct, interest in learning, and participation in school-related activities are three key areas of behavioral engagement According to Frederony et al 2004, in (Lester, 2013) This is evidenced by participant statements stating positive things related to Vocabulary learning using Animation. They all stated that the material provided was easier to understand than learning that did not use video, besides that they also liked to discuss with their peers or with the teacher if there was material they did not understand. This means that they are very involved in this learning. In addition, all participants said that they were very interested in continuing to learn using this Animated Video, because they thought this media was very helpful and facilitated their Vocabulary learning.

\section{Conclussion}

On cognitive engagement. Animated Videos can help students to learn and improve their vocabulary. Because this animated video is a medium that makes it easier for them to collect vocabulary, and easier to understand

On emotional engagement. There are several conveniences and difficulties in learning vocabulary using videos that the researchers found, including; Animated videos are interesting and fun media for participants because there are several things that increase student learning motivation. Such as songs, animated pictures etc., so that their vocabulary can increase after watching Animated Videos. Interesting media to continue as a Vocabulary learning tool. The rest there are no difficulties in learning to use animated videos

On engagement behavior. The level of student activity when learning to use this video is good. Because the media is interesting and easy to understand. This animated video can increase student activity in learning, students become more active in collecting assignments on time and discussing with the teacher if they do not understand the material.

\section{References}


Jurnal Edumaspul, 5 (2), Year 2021 - 781

(Sri Rahayu, Yousef Bani Ahmad, Acep Bahrum Kamil)

Braun, V., \& Clarke, V. (2006). Using thematic analysis in Psychology. Routlegde.

Harvey, R., \& McBean, E. (2015). A Data Mining Tool for Planning Sanitary Sewer Condition Inspection. ResearchGate.

Lester, D. (2013). A Review of the student Engagement Literature. FOCUS ON COLLEGES, UNIVERSITIES, AND SCHOOL.

Mart, C. T. (2012). Guessing the Meanings of Words from Context: Why and How. International Journal of Applied Linguistics \& English Literature.

Mashhadi, F., \& Jamalifar, G. (2015). Second Language Vocabulary Learning Through Visual and Textual Representation. ScienceDirect.

Masitah, R., Pamungkasari, E. P., \& Suminah. (2020). THE EFFECTIVENES OF ANIMATION VIDEO TO INCREASE ADOLESCENTS' NUTRITIONAL KNOWLEDGE. National Nutrition Journal.

Mo, Y., \& Singh, K. (2015). Parents' Relationships and Involment: Effects on Students' Engagement and Performance. Routledge.

Pravitasari, H., \& Yanto, E. S. (2020). A NARRATIVE INQUIRY OF STUDENTS TEACHERS
MULTIMODAL PRACTICE

EXPERIENCE IN THE

INDONESIAN ESP CLASSROOM

CONTEXT. The Englis Journal.

Sydorenko, T. (2010). Modality of Input and Vocabulary Acquisition. Language, Learning and Thecnology.

Zakirman, \& Hidayanti. (2017). PRAKTIKALITAS MEDIA VIDEO DAN ANIMASI DALAM PEMBELAJARAN FISIKA DI SMP. Jurnal Ilmiah Fisika AlBiruNi.

The first author is an English student at Singaperbangsa Karawang University, who is from Subang Answerarat. The author started his education at SDN Karangkamulyan in 2006, continuing his education to MTsN 2 Karawang, then to SMAN 1 Jatisari.

The second author is Yousef Bani Ahmad, S.S., M.Hum is a Lecturer in the Faculty of Teacher Training and Education in the English Education Study Program, at Singaperbangsa University, Karawang.

The third author, Acep Bahrum Kamil, S.Pd., M.Pd, is a lecturer at the Faculty of Teacher Training and Education in the English Language Study Program at Singeperbangsa University, Karawang. 